\title{
REMOVAL OF $\mathrm{Cd}^{2+}$ IONS FROM AQUEOUS SOLUTION USING LIVE AND DEAD Bacillus Subtilis
}

\author{
G. Vijayakumar', R. Tamilarasan², M. Dharmendra Kumar ${ }^{* 3}$ \\ ${ }^{1}$ Department of Chemistry, A.A. Govt. Arts College Musiri, Bharadhidasan University, India \\ ${ }^{2}$ Department of Chemistry, Anna University of Technology, Tiruchirappalli (Pattukottai Campus)-614 701, India \\ ${ }^{3}$ Department of Chemical Engineering, Anna University-Chennai, A.C. Tech Campus, Chennai-600 025, India
}

Received 2 December 2010; accepted 13 July 2011

\begin{abstract}
Biosorption of heavy metals is an effective process for the removal of toxic heavy metals present in the wastewater. An attempt is made in the present investigation to remove $\mathrm{Cd}^{2+}$ ions from aqueous solutions using B.subtilis. Batch experiments were carried out for $\mathrm{Cd}^{2+}$ removal over a wide range of operating conditions. It has been noticed that the $\mathrm{Cd}^{2+}$ removal capacity dependent on the initial $\mathrm{pH}$ and the initial $\mathrm{Cd}^{2+} \mathrm{concentra-}^{-}$ tion. Experimental data were analysed with kinetics and isotherm models. It has been observed that the pseudo second order kinetics and Freundlich isotherm equilibrium model fit well with the present data. The FTIR analysis of bacterial biomass revealed the presence of amino, carboxyl, hydroxyl and carbonyl groups, which are responsible for biosorption of $\mathrm{Cd}^{2+}$ metal ions. The results indicated that the biomass of B.subtilis is an efficient bioaccumulant for the removal of $\mathrm{Cd}^{2+}$ ions from aqueous solutions.
\end{abstract}

Keywords: Biosorption, $\mathrm{Cd}^{2+}$ removal, Kinetics, Isotherms, Bacillus subtilis-live and dead

DOI:10.3329/cerb.v15i1.6618

\section{Introduction}

The growth of industries and day to day changes in human activities has resulted in the increase in volume and complexity of wastewater in the environment. Industries such as, metal plating and tanneries uses heavy metal in their processes which generates large amount of aqueous effluents with high levels of heavy metals. The heavy metals include cadmium, chromium, cobalt, copper, iron, manganese, mercury, molybdenum, nickel, silver and zinc. Heavy metal pollution possess serious environmental issue due to its detrimental effect on human health. The removal and recovery of heavy metals from wastewater becomes important to protect the environment and human health. $\mathrm{Cd}^{2+}$ is one such heavy metal responsible for polluting the ecosystem. It is used in a large number of industrial processes such as alloy preparation, metal plating and electronics. $\mathrm{Cd}^{2+}$ effectively binds in human body with high molecular protein such as albumin and non-protein sulfhydryl group. This is accumulated in the kidneys and liver. Excess $\mathrm{Cd}^{2+}$ in the organisms can damage DNA sequencing and may cause genetic changes and cancer [1]. It also appears to be the largest single contributor to autoimmune thyroid disease [2]. Unlike organic pollutants, which can be degraded, metallic pollutants are immutable and

\footnotetext{
*Corresponding author Email: mdkumar@annauniv.edu; Ph: +91-44 22357260
}

will present indefinitely in the environment [3]. The non biodegradable nature and the carcinogenic nature of most of the metals lead to potential accumulation and human exposure via water or food [4]. Lead and zinc mines are the main sources for the release of lead, chromium and cadmium into the natural environment [5].

The traditional methods used for the removal of $\mathrm{Cd}^{2+}$ present in the effluent include precipitation, evaporation, adsorption on activated carbon, ion exchange membrane processing, and solvent extraction. However, these methods are expensive and inefficient to remove metals at low concentration [6-8]. The use of biological material, including living and non-living microorganisms, in the removal and possible recovery of toxic or precious metals from industrial wastes, has gained greater important in the recent years. The major advantages of the biosorption technology are its effectiveness in quickly reducing the concentration of heavy metal ions to very low levels with high efficiency by using inexpensive biosorbent materials [9].

The physicochemical interactions between metal ions and different functional groups on the biomass surface such as carboxyl, hydroxyl, sulfhydryl and amino groups play an important role in the biosorption process[10-16]. Living, dead and immobilized cells can be utilized in this process. Moreover, the regeneration of biosorbent for multiple uses is easy as; it shows selectivity towards the different metals removal. Bacteria have a high surface area-to-volume ratio that 
can provide a large contact interface, and this allows the interaction with metals from the surrounding environment. The advantages of biological substrates include diversity of biologically active binding sites and less interference from alkali/alkaline earth metals [17]. Microorganisms comprises of bacteria, algae, fungi and yeast which uptake metals either actively (bioaccumulation) and / or passively (biosorption) $[18,19]$. More recently, such as bacteria microbial biomass is specifically considered useful for removal of heavy metals from aqueous solutions [20, 21].

In this study, we evaluate the effectiveness in the removal of $\mathrm{Cd}^{2+}$ ions from aqueous solution through biosorption by dead and live B.subtilis and also to characterize the metal biosorption behavior of hyper resistant B.subtilis strain for $\mathrm{Cd}^{2+}$ ion. Pseudo first and second order kinetics and Langmuir and Freundlich isotherm parameters were also evaluated from batch biosorption assay. Bacteria B.subtilis is an alternative low-cost bioadsorbent for successful removal of $\mathrm{Cd}^{2+}$ from aqueous solutions. The high amount of $\mathrm{Cd}^{2+}$ uptake by B.subtilis places this biosorbent as the best adsorbent for this metal removal from aqueous solution.

\section{Materials and Methods}

\subsection{Preparation of the powdered dried dead cells}

B.subtilis (MTCC-121) species where purchased from Microbial type culture collection, Chandigarh, India. Nutrient broth culture media was prepared and maintained as per the guidelines of MTCC. The slant cultures were prepared with prescribed growth medium containing beef extract $1.0 \mathrm{~g}$, yeast extract $2.0 \mathrm{~g}$, peptone $5.0 \mathrm{~g}$, sodium chloride $5.0 \mathrm{~g}$ and distilled water 1.0 litre. The culture was sterilized in an autoclave maintained at $15 \mathrm{lbs}$ for 15 minutes. The chemical cadmium sulphate $\left(3 \mathrm{CdSO}_{4} \cdot 8 \mathrm{H}_{2} \mathrm{O}\right)$ used in the present investigation was of analytical grade purchased from Ranbaxy Fine Chemicals Ltd., India. Stock solution of $\mathrm{Cd}^{2+}(1000 \mathrm{mg} / \mathrm{l})$ was prepared using purified double distilled water. $\mathrm{Cd}^{2+}$ solutions of varying concentration were obtained by diluting the stock solution. The $\mathrm{Cd}^{2+}$ concentration was analyzed using an atomic absorption spectrophotometer (AAnalyst 800; PerkinElmer, USA). The morphology of bacteria has been analyzed using Scanning electron microscopy (JSM-6360; JEOL, Japan). Fourier transform infrared spectroscopy (FTIR; Model Tensor 27, Bruker Optic GmbH, Germany) spectrometer was used to determine the type of functional groups in bacteria responsible for the $\mathrm{Cd}^{2+}$ metal accumulation.

\subsection{Biosorption of $\mathrm{Cd}^{2+}$ ion}

The biosorption studies have been carried out with monometallic solutions prepared from stock solutions

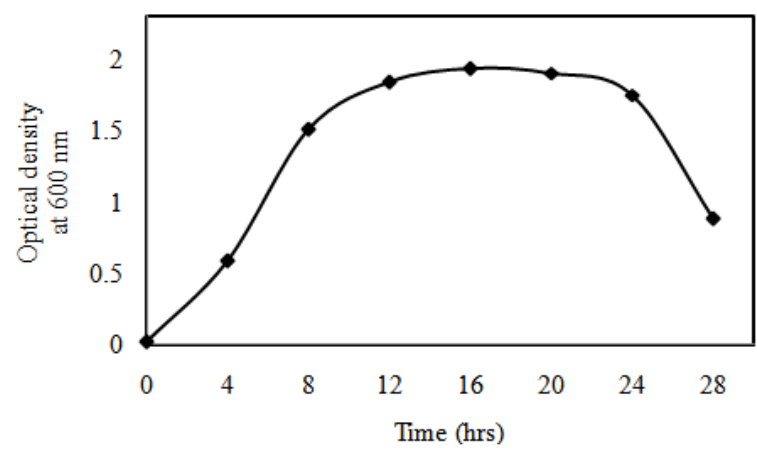

Figure 1: Growth curve of live B.subtilis in closed system optical density at $600 \mathrm{~nm}$

in a batch system. A known quantity of metal ion concentration solution was taken in flasks and biomass was added. The flasks were shaken at $150 \mathrm{rpm}$ in $30^{\circ} \mathrm{C}$ for a certain time of 0-24 hrs. Test samples were collected at regular intervals of time and centrifuged at $6000 \mathrm{rpm}$ for $10 \mathrm{~min}$, filtered through $0.2 \mu \mathrm{m}$ filter and analyzed for $\mathrm{Cd}^{2+}$ concentration using AAS.

\section{Results and Discussion}

\subsection{Effect of Growth curve}

During lag phase, B.subtilis adapts them to grow in a particular condition with closed system. This is the period where the individual B.subtilis are maturing and not yet able to divide. During the lag phase of the bacterial growth cycle, synthesis of RNA, enzymes and other molecules occurs. Exponential phase or log phase is a period characterized by cell doubling. The number of new bacteria appearing per unit time is proportional to the present population. If growth is not limited, doubling will continue at a constant rate so both the number of cells and the rate of population doubles with each consecutive time period. During stationary phase, the growth rate slows as a result of nutrient depletion and accumulation of toxic products. This phase is reached as the bacteria begin to exhaust the resources that are available to them. This phase has a constant rate value as the rate of bacterial growth is equal to the rate of bacterial death. At death phase, bacteria runs out of nutrients, no availability of space and oxygen lead to death. The growth rate of B.subtilis has been recorded for lag phase to dead phase and the observation is given in Figure 1. It can be ascertained that the lag phase exists for first 4 hrs followed by a consistent exponential pattern of increase in log phase for $12 \mathrm{hrs}$. The stationary phase exists for $20 \mathrm{hrs}$.

\subsection{Effect of metal ion concentration}

The effect of initial $\mathrm{Cd}^{2+}$ metal ion concentration in the range of 25 to $250 \mathrm{mg} / \mathrm{L}$ on adsorption was investigated at $30^{\circ} \mathrm{C}$. Figure 2 shows the biosorption 


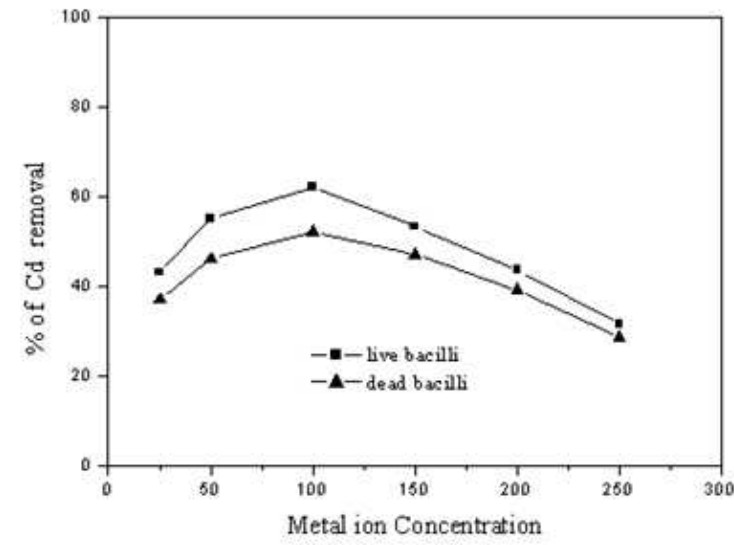

Figure 2: Effect of initial metal ion concentration on the biosorption of live B.subtilis and dead B.subtilis

for $\mathrm{Cd}^{2+}$ removal from the aqueous solution by live B.subtilis and dead B.subtilis respectively. It is evident from the figures that increase in initial concentration of $\mathrm{Cd}^{2+}$ leads to increase in uptake capacity of the B.subtilis is due to the interactions between metal ions and different functional groups of the biomass. It was noticed that the percentage cadmium uptake decrease with increase in initial concentration of cadmium. The decrease in percentage sorption as concentration increases may be as a result of reduction in the number of available functional groups on the adsorbents as the initial concentration is increased.

\subsection{Effect of pH on adsorption of the metal ions}

Figure 3 shows the change in sorption percentage of the metal ions on the adsorbents as a function of the solution $\mathrm{pH}$. the highest sorption percent removal observed for $\mathrm{Cd}^{2+}$ ion occur at $\mathrm{pH}$ of 5 . percentage removal for $\mathrm{Cd}^{2+}$ increased from 33 to $60 \%$ for $\mathrm{pH}$ increase from 2.0 to 6.0 and decreased to $29.78 \%$ at $\mathrm{pH} 10$ for sorption of live B.subtilis and dead B.subtilis respectively. The adsorption of $\mathrm{Cd}^{2+}$ ion on the adsorbent depends upon the nature of the adsorbent surface and the species distribution of the metal cation. At higher $\mathrm{pH}$ values, the functional groups on the surface of biosorbent will have negative charge. This could enhance electrostatic attraction between the metal cations the surface. This could account for highest sorption percent at $\mathrm{pH} 5$. The percent adsorption of metal ion decreased with the decrease in $\mathrm{pH}$, because protons compete with metal ions for sorption sites on the adsorbent surface.

\subsection{Adsorption Isotherms}

In biosorption, the metal ions accumulate on the surface of bacterium cell wall which can be well represented by a conventional accumulation isotherm. An attempt is made to test the Langmuir and Freundlich isotherms models for metal removal.

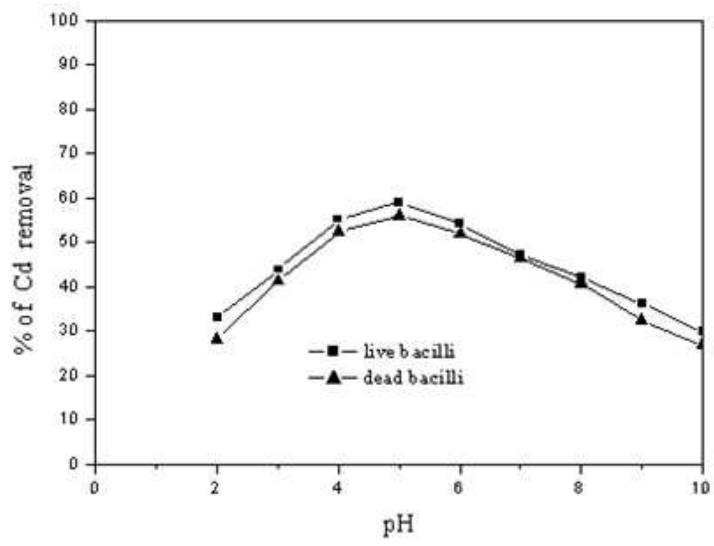

Figure 3: Effect of initial $\mathrm{pH}$ on the biosorption of $\mathrm{Cr}(\mathrm{VI})$ ion of live B.subtilis and dead B.subtilis

Table 1: Assignments of Infrared absorption bands

\begin{tabular}{lll}
\hline $\begin{array}{l}\text { Wave numbers } \\
\left(\mathrm{cm}^{-1}\right)\end{array}$ & Intensity shape & Assignment \\
\hline $3600-3750$ & Sharp & O-H stretching \\
$3400-3550$ & Sharp & O-H stretching \\
$3100-3500$ & Strong-broad & N-H stretching \\
$2500-3400$ & Weak-broad & O-H stretching \\
$2700-2950$ & Variable & C-H stretching \\
$1400-1660$ & Variable & N-H bending \\
$1280-1430$ & Variable & C-H bending \\
$1160-1420$ & Variable & O-H bending \\
$900-1350$ & Variable & C-N stretching \\
$900-1380$ & Variable & C-O stretching \\
$800-880$ & Medium-strong & N-H and C-H rocking \\
\hline
\end{tabular}

\subsubsection{Langmuir isotherm}

The Langmuir isotherm assumes monolayer adsorption on homogenous biosorbent surface (cell wall). The mathematical expression of Langmuir isotherm can be given as:

$$
q_{e}=\frac{K_{L} b C_{e}}{1+b C_{e}}
$$

The linearization of the above equation results in:

$$
\frac{C_{e}}{q_{e}}=\frac{1}{K_{L}}+\frac{a_{L}}{K_{L}} C_{e}
$$

The binding constant $K_{L}$, and the sorbent capacity $a_{L}$ are estimated by plotting $C_{e} / q_{e}$ against $C_{e}$. The model simulations along with experimental observations for $\mathrm{Cd}^{2+}$ with the experimental values of $K_{L}$ and $a_{L}$ along with the linear regression co-efficient $\left(R^{2}\right)$ are given Table 1 and Figure 4 respectively.

\subsubsection{Freundlich isotherm}

The Freundlich isotherm is an empirical model that relates the accumulation intensity of the sorbent to accumulants. The isotherm is adopted to describe reversible accumulation and not restricted to monolayer formation. The mathematical expression of the Freundlich isotherm model can be given as:

$$
q_{e}=K_{F} C_{e}{ }^{b_{F}}
$$




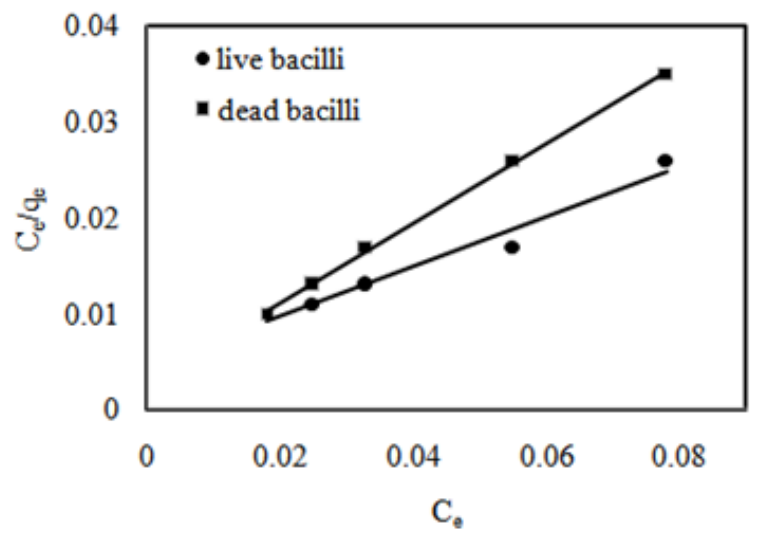

Figure 4: Langmuir isotherms of $\mathrm{Cd}^{2+}$ ion on live and dead biomass of Bacillus subtilis

Table 2: Langmuir and Freundlich isotherms constants for the biosorption of $\mathrm{Cd}^{2+}$ on live and dead of Bacillus subtilis

\begin{tabular}{crrr|rrr}
\hline \multirow{2}{*}{ Metal } & \multicolumn{3}{c|}{ Langmuir constant } & \multicolumn{3}{c}{ Freundlich constant } \\
\cline { 2 - 7 } & $K_{L}$ & $b$ & $R^{2}$ & $K_{F}$ & $b_{F}$ & $R^{2}$ \\
\hline Live & 0.003 & 2.861 & 0.889 & 1.563 & 8.796 & 0.993 \\
Dead & 0.011 & 2.401 & 0.998 & 1.216 & 3.505 & 0.998 \\
\hline
\end{tabular}

where $K_{F}$ and $b_{F}$ are the constants which give accumulation capacity and accumulation intensity respectively. A linear form of the Freundlich model can be written as follows

$$
\log q_{e}=\log K_{F}+b_{F} \log C_{e}
$$

A plot of $\log q_{e}$ versus $\log C_{e}$ gives a straight line with slope $K_{F}$ and intercept $b_{F}$. The values of $K_{F}$ and $b_{F}$ along with the linear regression co-efficient $\left(R^{2}\right)$ for the present experimental conditions have been obtained and are given in Table 2 and Figure 5. It can be observed from the correlation coefficient $\left(R^{2}\right)$ that the Freundlich isotherm model matches satisfactorily with the experimental observation.

\subsection{Adsorption Kinetics models}

In the sorption studies, equilibrium of sorption and sorption kinetics are two important physicochemical factors to be considered. Sorption kinetics can explain the dependency of sorption rates upon the concentrations of biosorbate in solution, and how sorption rates are affected by sorption capacity, or by the character of the sorbent [22]. Since the principles underlying biosorption kinetics include fitting the model that represents the experimental data best [23], the pseudofirst-order and the pseudo second order kinetic models were tested in our study.

\subsubsection{Pseudo first order model}

pseudo first order kinetic model by the following equation:

$$
\log \left(q_{e}-q_{t}\right)=\log \left(q_{e}\right)-\frac{k_{1} t}{2.303}
$$

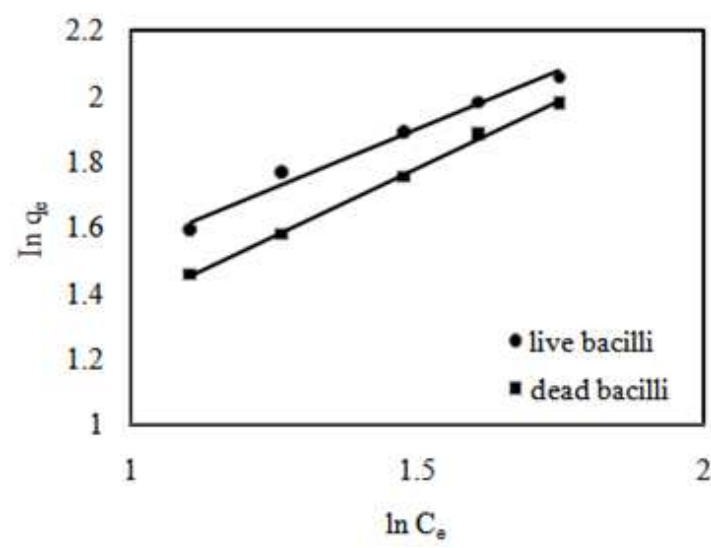

Figure 5: Freundlich isotherm of $\mathrm{Cd}^{2+}$ ion on live and dead biomass of Bacillus subtilis

Table 3: Kinetic data for the uptake by live and dead of Bacillus subtilis

\begin{tabular}{crrr|rrr} 
subtilis & \multicolumn{3}{c|}{ Pseudo first order } & \multicolumn{3}{c}{ Pseudo second order } \\
\cline { 2 - 7 } & $q_{e}$ & $K_{1}$ & $R^{2}$ & $q_{e}$ & $K_{2}$ & $R^{2}$ \\
\hline Live & 0.194 & 0.009 & 0.209 & 0.03 & 50 & 0.972 \\
Dead & 0.15 & 0.1087 & 0.289 & 0.013 & 370.37 & 0.996 \\
\hline
\end{tabular}

In place where $q_{e}$ and $q_{t}$ are the $\mathrm{Cd}^{2+}$ ions where sorbed at equilibrium and time $t$, respectively. $k_{1}$ is the rate constant for pseudo first order biosorption. This model was successfully applied to describe the kinetics for many adsorption systems. The kinetic data in Table 3 demonstrate that the biosorption of $\mathrm{Cd}^{2+}$ onto mixed biosorbent follow the negative pseudo first order kinetics.

\subsubsection{Pseudo second order model}

The adsorption kinetics in addition described by pseudo second order model. The linearized integral form of the model by the following equation:

$$
\frac{t}{q}=\frac{1}{k_{2} q_{e}^{2}}+\frac{t}{q_{e}}
$$

In Position $k_{2}$ is the pseudo second order rate constant and $q_{2}$ is the equilibrium biosorption capacity. Values of $k_{2}$ and $q_{2}$ were calculated from a plot of $t / q_{t}$ against $t$ in Figure 6. From Table 3 the $\left(R^{2}\right)$ values for the pseudo first order and the pseudo second order kinetic models indicated that the pseudo first order kinetic model could not explain the biosorption kinetics in our study. The values of equilibrium biosorption capacities from the pseudo second order kinetic model with $\left(R^{2}\right)$ values 0.972 and 0.996 for live and dead respectively.

\subsection{Fourier transform infrared spectroscopy}

The FTIR spectra of B.subtilis biomass before and after the metal uptake are shown in Figure 7 . It can be ascertained that the figure indicates the presence of amino, carboxylic, hydroxyl and carbonyl groups. It 


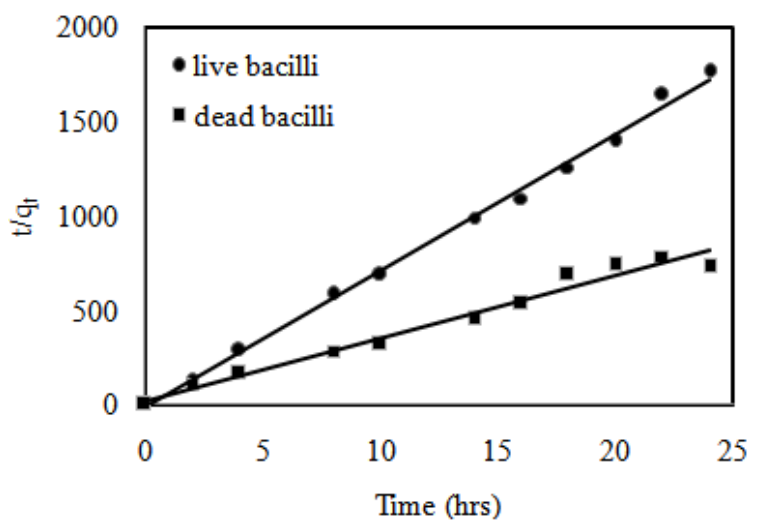

Figure 6: Pseudo second order kinetic modeling of $\mathrm{Cd}^{2+}$ adsorption on biomass of Bacillus subtilis

can be noticed from the figure that a strong broad and intense peak at $3400-3700 \mathrm{~cm}^{-1}$ shows the presence of hydrogen-bonded hydroxyl group. This also coupled with stretching vibration of the $\mathrm{NH}_{2}$ moiety (Table 1). A strong absorption at $1050 \mathrm{~cm}^{-1}$ shows the stretching of $\mathrm{C}-\mathrm{O}$ in polysaccharides [24]. Both live and dead B. subtilis were subjected for $\mathrm{Cd}^{2+}$ accumulation. Samples were taken at regular intervals and analyzed by using FTIR spectra. A peak at 1280 and 1470 $\mathrm{cm}^{-1}$ has been observed for all intervals of time which shows the presence of carboxylic and amide groups. While the peak at 885 and $618 \mathrm{~cm}^{-1}$ during the first 12 hrs represent the stretching and bending modes. It can be noticed from figure that the IR spectrum for all intervals of time except $24 \mathrm{hrs}$ shows a peak with strong vibration at 1280 and $1470 \mathrm{~cm}^{-1}$, represents presence of $\mathrm{C}-\mathrm{H}$ bonding. Finally the peaks at $2950-3000 \mathrm{~cm}^{-1}$ with $\mathrm{CH}_{2}$ stretching frequency shows the participation of $\mathrm{OH}$ and $\mathrm{NH}_{2}$. The analysis of the FTIR spectra showed the presence of ionisable functional groups (carboxyl, amino, amide and hydroxyl) able to interact with protons or metal ions. The above results obtained give an idea about the presence of functional groups on the bacterial cell surfaces.

\subsection{Scanning electron microscopy}

The Scanning electron microscopy (SEM) images clearly reveal that the surface texture and morphology of the biosorbent are shown in Figure 8 and 9, which represent with and without $\mathrm{Cd}^{2+}$ ions, with different magnifications. The length and width of the filament of live B.subtilis varies from 1.0 to $2.5 \mu \mathrm{m}$ and 0.3 to $0.8 \mu \mathrm{m}$ and as expected the cell shrinks when it is dried. In dry species the length and width of the bacilli lies in the range of 0.6 to $1.8 \mu \mathrm{m}$ and 0.1 to 0.4 $\mu \mathrm{m}$. The difference in the surface morphology after the metal uptake by live and dead species is evident from SEM images. The surface of the biomass becomes rough after metal uptakes. It has already been stated in the previous sections of IR spectroscopy and

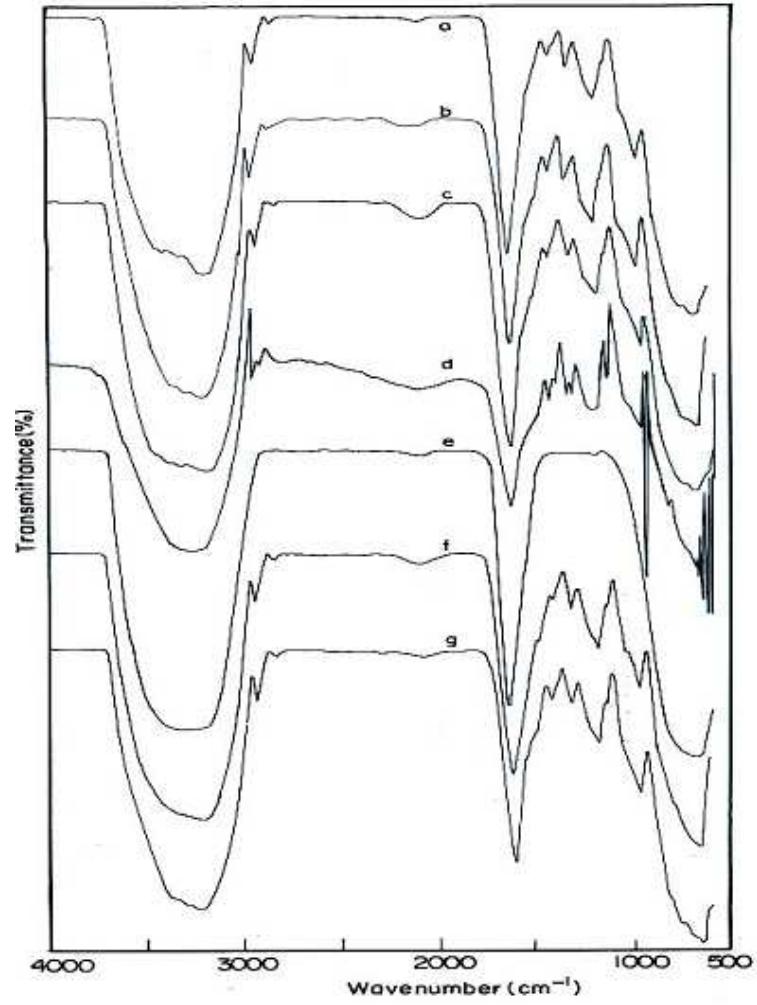

Figure 7: Infra spectra of (a) live B.subtilis were treated with $\mathrm{Cd}^{2+}$ ions for different lengths of time namely (b) 0.0 , (c) 0.2 , (d) 0.12 , (e) $0.24 \mathrm{hrs}$, (f) dead B.subtilisand (g) dead $\mathrm{Cd}^{2+}$ ion

kinetic study that live B.subtilis takes up more metal ions than the dead one. A close examination of the SEM micrograph of the treated samples also supports this fact; the width of the cell of treated live biomass is more compared to the same for dried species. When treated with metal of $\mathrm{Cd}^{2+}$ ions there is the possibility of transport of $\mathrm{Cd}^{2+}$ ions through the cell membrane in live biomass that may be responsible for more uptakes in this B.subtilis. The SEM micrograph of metaltreated live B.subtilis shows metal ions protruding in the strand of the cell, supporting membrane transport process.

\section{Conclusion}

The presented study is based on the biosorption of B.subtilis on $\mathrm{Cd}^{2+}$ ions by live and dead biomass. The metabolic activities in live B.subtilis possibly help in higher uptake of metal ions compared to dead species. The sorption process for live biomass using Freundlich model given a good correlation coefficient and in the case of dead biomass both isotherms are obeyed. The uptake of $\mathrm{Cd}^{2+}$ ions by live and dead B. subtilis follows pseudo second-order rate equation. The Infra red spectra suggest the participation of carboxylate, hydroxyl of polysaccharides, phosphate and amide groups in the uptake. SEM and microscopic studies support the 


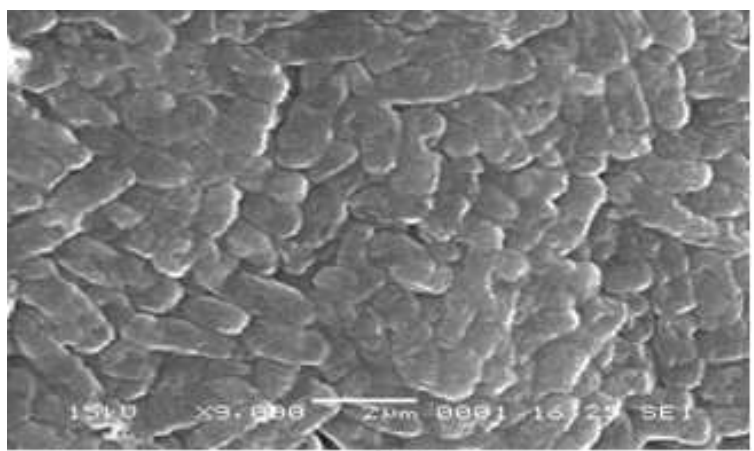

(A)

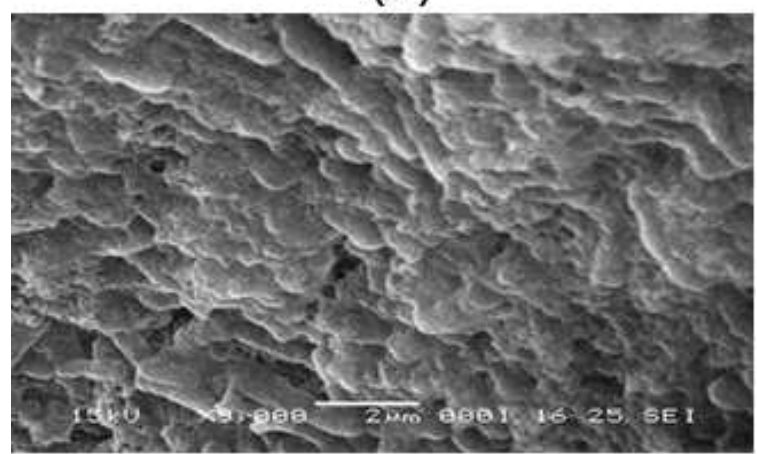

(B)

Figure 8: SEM Images represent live bacilli A and dead bacilli B before accumulation on B.subtilis without the presence of $\mathrm{Cd}^{2+}$

sorption data. Consequently, removal of $\mathrm{Cd}^{2+}$ live and dead B.subtilis took up significant amount of $\mathrm{Cd}^{2+}$ ions. In this live B.subtilis were found to be simple, abundantly available, cost effective fast, and efficient.

\section{References}

[1] Carmichael WW, The toxins of cyanobacteria, Scientific American, 1994. 270(1):pp. 64-70

[2] Der R, Yousef M, Fahim Z and Fahim M, Effects of lead and cadmium on adrenal and thyroid functions in rats, $\mathrm{Re}-$ search communications in chemical pathology and pharmacology, 1977. 17(2):pp. 237-253

[3] Sharma P, Kumari P, Srivastava MM and Srivastava S, Removal of cadmium from aqueous system by shelled Moringa oleifera Lam. seed powder, Bioresource technology, 2006. 97(2):pp. 299-305

[4] Villaescusa I, Fiol N, Martinez M, Miralles N, Poch J and Serarols J, Removal of copper and nickel ions from aqueous solutions by grape stalks wastes, Water Research, 2004. 38(4):pp. 992-1002. doi:10.1016/j . watres. 2003.10.040

[5] Liu H, Probst A and Liao B, Metal contamination of soils and crops affected by the Chenzhou lead/zinc mine spill (Hunan, China), Science of the Total Environment, 2005. 339(1-3):pp. 153-166. doi:10.1016/j.scitotenv.2004.07.030

[6] Rickelton WA, The removal of cadmium impurities from cobaltnickel solutions by precipitation with sodium diisobutyldithiophosphinate, Hydrometallurgy, 1998. 50(3):pp. 339 - 344. doi : 10.1016/S0304-386X (98) 00063-2

[7] Wombacher F, Rehkamper M and Mezger K, Determination of the mass-dependence of cadmium isotope fractionation during evaporation1, Geochimica et cosmochimica acta, 2004. 68(10):pp. 2349-2357. doi:10.1016/j.gca.2003.12.013

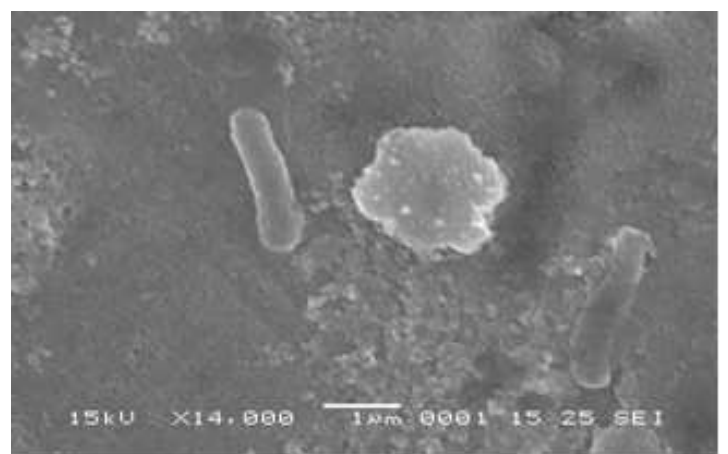

(A)

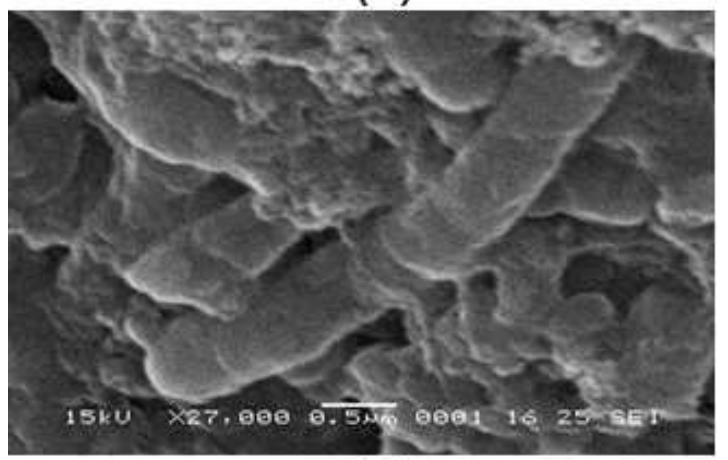

(B)

Figure 9: SEM Images represent live bacilli A and dead bacilli B after accumulation in B.subtilis with presence of $\mathrm{Cd}^{2+}$

[8] Selatnia A, Bakhti M, Madani A, Kertous L and Mansouri $\mathrm{Y}$, Biosorption of $\mathrm{Cd}^{2+}$ from aqueous solution by a NaOH-treated bacterial dead Streptomyces rimosus biomass, Hydrometallurgy, 2004. 75(1-4):pp. 11-24. doi:10.1016/j.hydromet.2004.06.005

[9] Volesky B, Sorption and Biosorption, BV Sorbex, Inc., Montreal, Canada, 2003, pp.:81-102, Website: www.biosorption.com/order

[10] Marandi R, Biosorption of Hexavalent Chromium from Aqueous Solution by Dead Fungal Biomass of Phanerochaete crysosporium: Batch and Fixed Bed Studies, Canadian Journal on Chemical Engineering \& Technology, 2011. 2(2):pp. 8-22

[11] Kratochvil D, Fourest E and Volesky B, Biosorption of copper by Sargassum fluitans biomass in fixed-bed column, Biotechnology letters, 1995. 17(7):pp. 777-782. doi: $10.1007 / \mathrm{BF} 00130368$

[12] Volesky B and Holan ZR, Biosorption of heavy metals, Biotechnology Progress, 1995. 11:pp. 235-250

[13] Fourest E and Volesky B, Contribution of sulfonate groups and alginate to heavy metal biosorption by the dry biomass of Sargassum fluitans, Environmental Science \& Technology, 1990. 30:pp. 277-282. doi:10.1021/es950315s

[14] Kratochvil D and Volesky B, Advances in the biosorption of heavy metals, Trends in Biotechnology, 1998. 16:pp. 291-300. doi:10.1016/S0167-7799 (98)01218-9

[15] Yu Q, Matheickal JT, P Y and Kaewsarn P, Heavy metal uptake capacities of common marine macro algal biomass, Water Research, 1999. 23:pp. 1534-1537. doi:10.1016/S0043-1354(98) 00363-7

[16] Mungasavalli DP, Viraraghavan T and Jin YC, Biosorption of aqueous solution by pretreated Aspergillus. niger, batch and column studies, Colloids and Surfaces, 2007. 301:pp. 214223. doi:10.1016/j.colsurfa.2006.12.060

[17] Madrid Y and Camara C, Biological substrates formetal preconcentration and speciation, Trends 
in Analytical Chemistry, 1997. 16:pp. 36-44. doi: 10.1016/S0165-9936(96)00075-1

[18] Hussein H, Ibrahim SF and Kandeel K, Biosorption of heavy metals from waste water using Pseudomonas sp., Electronic Journal of Biotechnology, 2004. 7(1):pp. 38-46. doi:10.2225/vol7-issue1-fulltext-2

[19] Yan G and Viraraghavan T, Effect of pretreatment on the bioadsorption of heavy metals on Mucor rouxii, Water South Africa, 2000. 26(1):pp. 119-124

[20] Nourbakhsh M, Kiliçarslan S, Ilhan S and Ozdag H, Biosorption of $\mathrm{Cr}^{6+}, \mathrm{Pb}^{2+}$ and $\mathrm{Cu}^{2+}$ ions in industrial waste water on Bacillus sp., Chemical Engineering Journal, 2002. 85(2-3):pp. 351-355. doi : 10.1016/S1385-8947 (01) 00227-3

[21] Ahluwalia SS and Goyal D, Microbial and plant derived biomass for removal of heavy metals from wastewater, Bioresource Technology, 2007. 98(12):pp. 2243-2257. doi:10.1016/j.biortech.2005.12.006

[22] Ho YS, Ng JCY and McKay G, Kinetics of pollutant sorption by biosorbents: review, Separation and purification methods, 2000. 29(2):pp. 189-232. doi:10.1081/SPM-100100009

[23] Kuppasamy V, Joseph RJ, Kandasamy P and Manicakam V, Copper removal from aqueous solution by marine green alga Ulva reticullata, Electronic Journal of Biotechnology, 2004. 7:pp. 61-71. doi:10.2225/vol7-issue1-fulltext-4

[24] Aravindhan R, Madhan B, Rao JR, Nair BU and Ramasami $\mathrm{T}$, Bioaccumulation of chromium from tannery wastewater: an approach for chrome recovery and reuse, Environmental science \& technology, 2004. 38(1):pp. 300-306. doi:10.1021/es034427s 